\title{
Synthesis and characterisation of fluorescent aminophosphines and their coordination to gold(I)
}

Lara M. Groves, ${ }^{a}$ Benjamin D. Ward, ${ }^{a}$ Paul D. Newman, ${ }^{a}$ Peter N. Horton, ${ }^{b}$ Simon J. Coles, ${ }^{b}$ Simon J.A. Pope*a

a. $\quad$ School of Chemistry, Main Building, Cardiff University, Cardiff CF10 3AT. Fax: (+44) 029-20874030; Tel: (+44) 029-20879316; E-mail: popesj@cardiff.ac.uk.

b. UK National Crystallographic Service, Chemistry, Faculty of Natural and Environmental Sciences, University of Southampton, Highfield, Southampton, SO17 1BJ, England.

\section{Abstract}

Three novel fluorescent aminophosphine ligands have been synthesised that incorporate napthyl (L1), pyrenyl (L2) and anthraquinone (L3) chromophores into their structures. The ligands react with $[\mathrm{AuCl}(\mathrm{tht})]$ (tht = tetrahydrothiophene) to give neutral complexes of the form [AuCl(L1-3)]. Solid state, X-ray crystallographic data was obtained for the anthraquinone derivative, $[\mathrm{AuCl}(\mathbf{L} \mathbf{3})]$, and showed a distorted linear coordination geometry at $\mathrm{Au}(\mathrm{I})$. The packing structure also revealed a number of intermolecular $\pi$ - $\pi$ interactions that involve the anthraquinone and phenyl units of the aminophosphine ligand. ${ }^{31} \mathrm{P}$ NMR spectroscopic data revealed $\delta_{\mathrm{p}}$ values of +42.2 (L1), +42.1 (L2) and +26.1 (L3) ppm, which shifted downfield upon coordination to $\mathrm{Au}(\mathrm{I})$ to $+64.6,+64.7$, and $+55.8 \mathrm{ppm}$, respectively. Supporting TD-DFT studies were able to reproduce the structure and ${ }^{31} \mathrm{P}$ NMR chemical shifts of $[\mathrm{AuCl}(\mathrm{L} \mathbf{3})]$ as well as rationalise the HOMO-LUMO compositions. Photophysical studies showed that the appended fluorophore dominates the absorption and emission properties for the ligands and complexes, with the anthraquinone derivatives showing visible emission at $c a .570 \mathrm{~nm}$ which was attributed to the intramolecular charge transfer character of the phosphinoaminoanthraquinone fragment.

\section{Introduction}

Aminophosphines of the type $\mathrm{R}_{2} \mathrm{~N}-\mathrm{PR}_{2}$ (also referred to as aminophosphanes or phosphinous amides) are a well-known class of phosphorus compound. ${ }^{\mathrm{i}, \mathrm{ii}}$ They can be commonly synthesised from a phosphinous chloride $\left(\mathrm{R}_{2} \mathrm{PCl}\right)$ and a nucleophilic amine in the presence of base. Although, the $\mathrm{P}-\mathrm{N}$ bond can be quite sensitive to air and moisture, the nitrogen centre does provide opportunities for controlling the physical properties and reactivity of aminophosphines. Interest in aminophosphines has been 
primarily driven by their use as reagents to new heterocyclic organophosphorus species, and their application in coordination chemistry (although when compared to phosphine ligands this area is still relatively immature).

Examples of pioneering work on the coordination chemistry of aminophosphines were conducted by Woollins and co-workers. ${ }^{\text {iii }}$ Synthetic approaches, including those by Dyer, potentially allow access to mixed donor ligands with adaptable chelating properties. ${ }^{\text {iv }}$ Importantly, complexes that incorporate aminophosphines have been deployed as catalysts for several transformations, including Suzuki-Miyaura, ${ }^{v}$ asymmetric hydrosilylation ${ }^{\mathrm{vi}}$ reactions and allylic

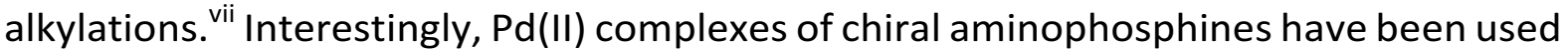
for the enantiodiscrimination of amino acids using ${ }^{31}$ P NMR spectroscopy. viii

In our ongoing studies investigating new ligand architectures that can impart fluorescent properties upon $\mathrm{Au}(\mathrm{I})$ coordination complexes ${ }^{\mathrm{ix}}$, aminophosphines present an ideal class of compound that have yet to be fully explored. Examples are rare, but in the early 2000s Zhang and co-workers reported a series of papers that described the $\mathrm{Au}(\mathrm{I})$ coordination chemistry of anthracene-based aminophosphine ligands together with their fluorescence properties. $^{\mathrm{x}} \quad$ In fact, examples of fluorescent phosphine-based ligands are also relatively sparse. Notable cases include Bodipy-tagged systems developed by Higham ${ }^{\mathrm{xi}}$ that have been successfully explored in cell imaging work. ${ }^{\text {xii }}$ The $A u(I)$ complexes of related Bodipy-phosphine dyads have been investigated in gold-catalyzed alkyne transformations. ${ }^{\text {iii }}$ Recently, Gabbai has demonstrated that a fluorescein-appended tertiary phosphine can be used as a "sensor" for $\mathrm{Au}$ (III) ions by modulating photoinduced electron transfer between the phosphorus atom and fluorophore. ${ }^{\text {xiv }}$ Other examples of fluorophore-functionalised phosphines have sought to manipulate the reactivity of phosphorus in the detection of reactive oxygen species (ROS). ${ }^{\mathrm{x}}$ Similar approaches utilising aminophosphine architectures have not been reported.

In a biological context, a small handful of aminophosphine complexes of gold(I) have been reported in recent years and have shown some promise as antibacterial agents. ${ }^{x v i}$ In this current work, we describe our progress in the synthesis and characterisation of fluorescent aminophosphine derivatives and explore their coordination chemistry with $\mathrm{Au}(\mathrm{I})$. Our strategy is represented in Scheme 1, wherein the fluorescent component of the ligand is added via the choice of amine. We present details of the spectroscopic properties of these species together with an example of a structurally characterised fluorescent aminophosphine $\mathrm{Au}(\mathrm{I})$ complex. 


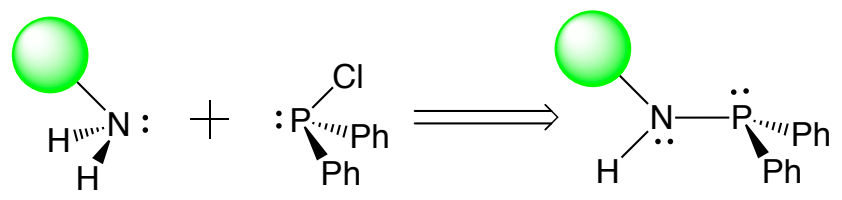

FLUORESCENT

AMINOPHOSPHINE

$=$ FLUOROPHORE

Scheme 1. Cartoon representation of a fluorophore appended aminophosphine.

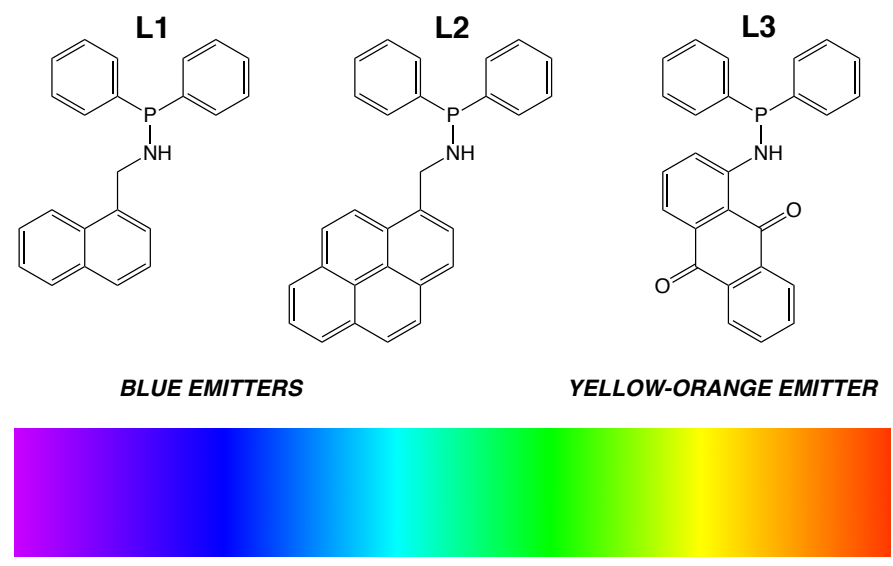

Scheme 2. Structures of the aminophosphine fluorophores isolated in this work.

\section{Results and Discussion}

\section{Synthesis}

The aminophosphine ligands (L1-L3) (Scheme 2) were synthesised in a single step from chlorodiphenylphosphine $\left(\mathrm{Ph}_{2} \mathrm{PCl}\right)$ and the relevant primary amine (1naphthalenemethylamine, 1-pyrenemethylamine, 1-aminoanthraquinone). The phosphine was added dropwise to a stirred, degassed dichloromethane solution of the amine in the presence of base (triethylamine) at $0{ }^{\circ} \mathrm{C}$. $\mathbf{L} \mathbf{1}$ and $\mathbf{L 2}$ were isolated as colourless and yellow oils, respectively, while the anthraquinone derivative L3 was obtained as a dark orange solid. The formation of L3 is noteworthy as the amine of 1aminoanthraquinone is far less basic, and is delocalised into the strongly electron withdrawing anthraquinone ring. All ligands were assumed to be, and treated as, air/moisture-sensitive materials and were stored under an inert atmosphere. The 
corresponding gold(I) complexes were synthesised by stirring [AuCl(tht)] (where tht $=$ tetrahydrothiophene) with the ligand in deoxygenated dichloromethane to yield airstable species. Further purification of $[\mathrm{AuCl}(\mathrm{L3})]$ was achieved using column chromatography (silica) without any notable degradation of the product.

\section{Spectroscopic Characterisation of Ligands and Complexes}

Multinuclear NMR spectroscopy was used to confirm the proposed structures of the ligands. In the first instance, ${ }^{31} \mathrm{P}$ NMR chemical shift data (Table 1) gave immediate indication of the formation of the target aminophosphine. For structurally related L1 and L2, which incorporate a methylamine unit, this value is approximately $+42 \mathrm{ppm}$, which is comparable to the handful of reports on chemical shift values for $\mathrm{Ph}_{2}(\mathrm{RHN}) \mathrm{P}$ type species ( +40 to $+70 \mathrm{ppm}) .{ }^{4}$ For $\mathbf{L} 3$ the ${ }^{31} \mathrm{P}\left\{{ }^{1} \mathrm{H}\right\}$ NMR chemical shift value appeared at a relatively upfield value around +26 ppm suggesting that the phosphorus nucleus is more shielded in the aminoanthraquinone derivatives. This value is consistent with the report of Woollins et al who described the reactivity of an arylamine with $\mathrm{Ph}_{2} \mathrm{PCl}$ to give a corresponding aminophosphine with a recorded ${ }^{31} \mathrm{P} N M R$ resonance at approximately +27 ppm. .vii $^{\text {iim }}$

In the ${ }^{1} \mathrm{H}$ NMR spectra of $\mathbf{L} 1$ and $\mathbf{L 2}$, the $\mathrm{NH}$ resonance gave rise to a complex multiplet around $2.3 \mathrm{ppm}$ due to both ${ }^{3} J_{\mathrm{HH}}$ and ${ }^{2} J_{\mathrm{HP}}$ coupling. The methylene resonances for $\mathbf{L} \mathbf{1}$ and $\mathbf{L} \mathbf{2}$ were observed at 4.44 and $4.67 \mathrm{ppm}$, respectively. In $\mathbf{L} \mathbf{3}$ the $\mathrm{NH}$ resonance appeared much further downfield at $c a .10 .3 \mathrm{ppm}$, due to the strongly electron withdrawing anthraquinone unit, and presented as a doublet, which is attributed to $\mathrm{H}-\mathrm{P}$ coupling $\left({ }^{2} J_{\mathrm{HP}}=7.3 \mathrm{~Hz}\right)$. This is consistent with previous work on substituted aminoanthraquinones which often show such resonances at chemical shifts above 9 ppm. ${ }^{\text {viii }}$ For $\mathbf{L} 3$, the ${ }^{13} \mathrm{C}\left\{{ }^{1} \mathrm{H}\right\}$ NMR spectrum revealed the two unique carbonyl carbons at 186.4 and $183.5 \mathrm{ppm}$ due to the unsymmetrical nature of the anthraquinone moiety. In L1 and L2, the methylene carbon resonances were noted as doublets $\left({ }^{2} J_{\mathrm{CP}} \sim 16 \mathrm{~Hz}\right)$ ca. $48 \mathrm{ppm}$, again consistent with the formation of the aminophosphine. The number of aromatic resonances suggest that the phenyl groups are inequivalent (suggesting restricted rotation). High resolution mass spectrometry (HRMS) was obtained for each ligand confirming the proposed formulation. IR spectra 
of the ligands allowed identification of $v(N-H)$ and in the case of $L 3, v(C=O)$ stretching frequencies.

Table 1. The ${ }^{31} \mathrm{P}$ NMR chemical shift values for the ligands and complexes. Selected comparative calculated values are included in parentheses.

\begin{tabular}{ccc}
\hline Compound & ${ }^{\mathrm{I}} \mathrm{P}, \delta / \mathrm{ppm}$ & $\left(\delta_{\text {complex }}-\delta_{\text {ligand }}\right) / \mathrm{ppm}$ \\
\hline L1 & +42.2 & - \\
L2 & +42.1 & - \\
L3 & $+26.1(+26.8)$ & - \\
& & +22.4 \\
{$[\mathrm{AuCl}(\mathbf{L 1})]$} & +64.6 & +22.6 \\
{$[\mathrm{AuCl}(\mathrm{L2})]$} & +64.7 & +29.7 \\
{$[\mathrm{AuCl}(\mathrm{L3})]$} & $+55.8(+49.9)$ & \\
\hline
\end{tabular}

The $\mathrm{Au}(\mathrm{I})$ complexes were similarly characterised with an array of techniques. Firstly, ${ }^{31} \mathrm{P}\left\{{ }^{1} \mathrm{H}\right\}$ NMR (Table 1) spectra revealed significant downfield shifts (up to around $+30 \mathrm{ppm}$ ) for each of the complexes relative to the free ligands, consistent with coordination to $A u(I)$. As with the corresponding ligands, the phosphorus resonances for $[\mathrm{AuCl}(\mathbf{L} \mathbf{1})]$ and $[\mathrm{AuCl}(\mathbf{L} \mathbf{2})]$ were very similar (ca. $+65 \mathrm{ppm})$, while $[\mathrm{AuCl}(\mathrm{L3})]$ appeared around $+56 \mathrm{ppm} .{ }^{1} \mathrm{H}$ NMR spectra showed retention of the fluorophore labelled aminophosphine in each case (with the requisite number of aromatic resonances), and for $[\mathrm{AuCl}(\mathbf{L} \mathbf{1})]$ and $[\mathrm{AuCl}(\mathbf{L 2})]$ the methylene resonances were shifted downfield by around $+0.2 \mathrm{ppm}$ upon formation of the complexes. These spectra also show the $\mathrm{NH}$ resonance, again confirming the integrity of the aminophosphine upon coordination to $\mathrm{Au}(\mathrm{I})$. For $[\mathrm{AuCl}(\mathrm{L} \mathbf{3})]$ the ${ }^{13} \mathrm{C}\left\{{ }^{1} \mathrm{H}\right\}$ NMR spectrum showed a subtle shift in the carbonyl carbon resonances of the anthraquinone unit, while for $[\mathrm{AuCl}(\mathbf{L 1})]$ and $[\mathrm{AuCl}(\mathrm{L2})]$ the methylene carbon was again noted around $48 \mathrm{ppm}$. HRMS data was obtained for each of the complexes again supporting their successful formation.

\section{X-ray Crystallography}

During the synthesis of the ligands and complexes, diffraction quality crystals of $[\mathrm{AuCl}(\mathrm{L3})]$ were isolated. These were obtained via recrystallisation from acetonitrile and diethyl ether. Data collection parameters are shown in the Experimental section, 
together with supporting bond length and bond angle data (Table 2). The resultant structure of $[\mathrm{AuCl}(\mathrm{L} \mathbf{3})]$ is shown in Figures 1 and 2.

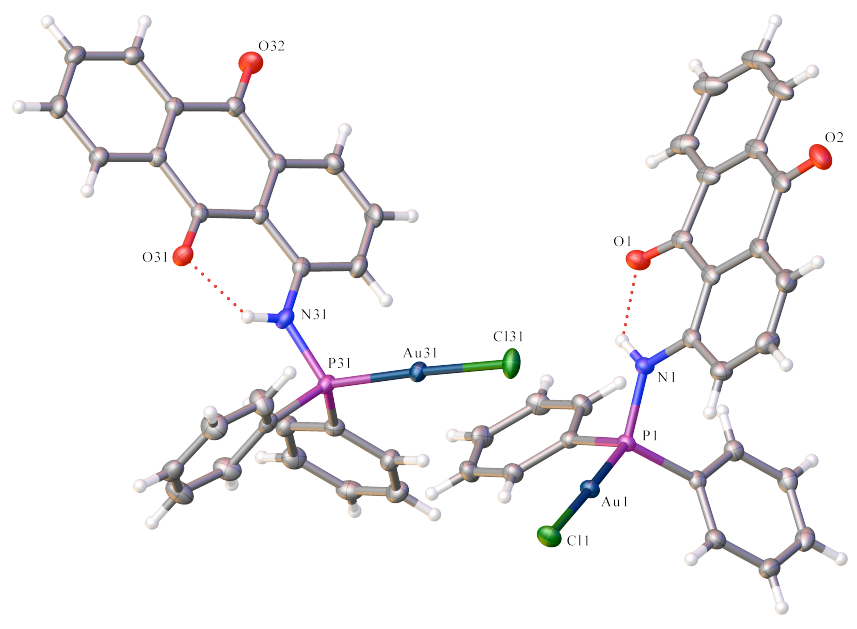

Figure 1. Crystal structure of $[\mathrm{AuCl}(\mathrm{L} 3)]$. Ellipsoids drawn at $50 \%$ probability.

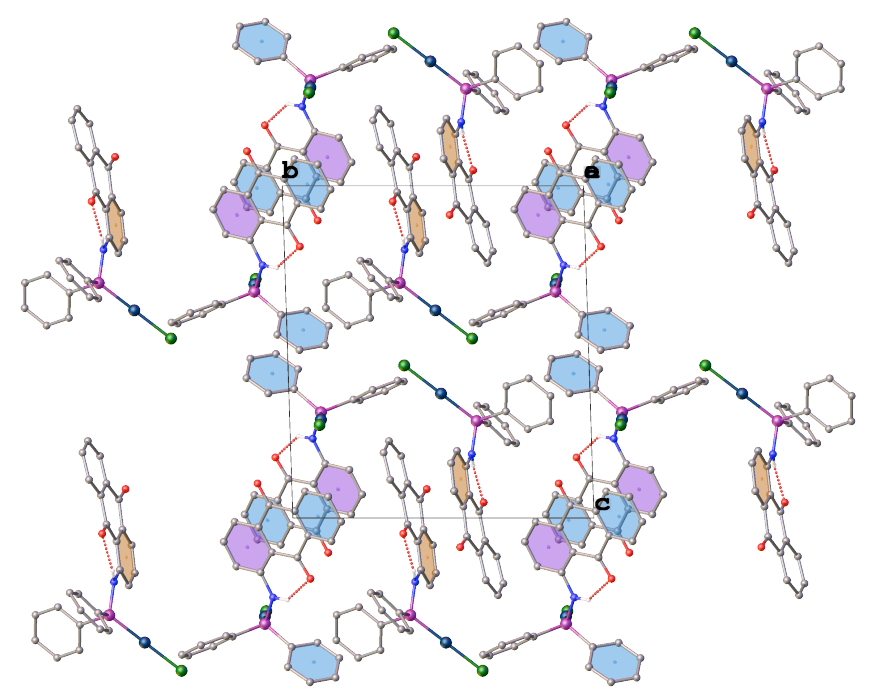

Figure 2. Packing diagram for $[\mathrm{AuCl}(\mathrm{L} 3)]$.

Table 2. Selected bond lengths and bond angles for $[\mathrm{AuCl}(\mathrm{L3})]$.

\begin{tabular}{cccc}
\multicolumn{4}{c}{ Selected bond lengths (Å) } \\
\hline $\mathrm{Au}(1)-\mathrm{Cl}(1)$ & $2.2874(5)$ & $\mathrm{Au}(31)-\mathrm{Cl}(31)$ & $2.2900(6)$ \\
$\mathrm{Au}(1)-\mathrm{P}(1)$ & $2.2225(6)$ & $\mathrm{Au}(31)-\mathrm{P}(31)$ & $2.2224(6)$ \\
$\mathrm{P}(1)-\mathrm{N}(1)$ & $1.6774(19)$ & $\mathrm{P}(31)-\mathrm{N}(31)$ & $1.6851(19)$ \\
& \multicolumn{4}{c}{$\mathrm{Au}-\mathrm{Cl}$} & 2.356 (calc) \\
& $\mathrm{Au}-\mathrm{P}$ & 2.296 (calc) \\
& $\mathrm{P}-\mathrm{N}$ & 1.698 (calc) \\
& \multicolumn{4}{c}{ Selected bond angles (Å) } \\
\hline $\mathrm{P}(1)-\mathrm{Au}(1)-\mathrm{Cl}(1)$ & $178.38(2)$ & $\mathrm{P}(31)-\mathrm{Au}(31)-\mathrm{Cl}(31)$ & $176.75(2)$ \\
$\mathrm{N}(1)-\mathrm{P}(1)-\mathrm{Au}(1)$ & $116.88(7)$ & $\mathrm{N}(31)-\mathrm{P}(31)-\mathrm{Au}(31)$ & $117.38(7)$ \\
\hline
\end{tabular}


The X-ray crystal structure for $[\mathrm{AuCl}(\mathrm{L} 3)]$ confirms the suggested formulation in the solid state (Figure 1). Within the structure there are two independent molecules within the asymmetric unit. The two molecules are very similar to each other, varying by different twist angles for one of the phenyl rings and the anthraquinone (see Figure S1, ESI). The structure reveals the integrity of the anthraquinone functionalised aminophosphine and its coordination to $\mathrm{Au}(\mathrm{I})$. The complex adopts an approximately linear coordination geometry at $\mathrm{Au}(\mathrm{I})$ with $\angle \mathrm{P}-\mathrm{Au}-\mathrm{Cl}$ in the range $176.75(2)-178.38(2)$. The Au-P and Au-Cl bond lengths are around $2.22 \AA$ and $2.29 \AA$, respectively. The P-N distances of 1.6774(19) and 1.6851(19) A can be regarded as relatively short when compared to other aminophosphines; ${ }^{1}$ a previously reported $\mathrm{Pt}(\mathrm{II})$ complex of a bisaminophosphine has a comparable P-N distance of 1.6843(19) $\AA^{\text {xix }}$

The structure also reveals intramolecular hydrogen bonding interactions of $c a .1 .90 \AA$ between the $\mathrm{N}-\mathrm{H}$ and $\mathrm{C}=\mathrm{O}$ groups of the anthraquinone moiety. These interactions support the orientation of the P-N bonds which are close to the plane of the anthraquinone $\left(1.73(8)^{\circ}\right.$ or $\left.15.55(8)^{\circ}\right)$. The packing arrangement for $[\mathrm{AuCl}(\mathrm{L3})]$ (Figure 2) revealed intermolecular $\pi-\pi$ interactions between the phenyl rings of the anthraquinone unit, and the phenyl rings of the diphenylphosphine moiety (details in table S1, ESI). The closest interactions are between the anthraquinones of neighbouring complex units. There are no aurophilic interactions revealed by this structure, presumably due to the significant steric constraints of the aminophosphine ligand.

The steric properties of $\mathbf{L} \mathbf{3}$ have also been assessed from the crystal data by use of the SambVca 2 program ${ }^{\mathrm{xx}}$ for determination of buried volume $\left(\% \mathrm{~V}_{\text {bur }}\right)$ and the method of Mingos ${ }^{\mathrm{xxi}}$ for deriving crystallographic cone angles. The $\% \mathrm{~V}_{\text {bur }}$ values for the two independent molecules in the unit cell are $32.0^{\circ}$ and $32.9^{\circ}$ respectively, with attendant cone angles of $163^{\circ}$ and $169^{\circ}$. These relatively large values reflect the absence of any steric hindrance at the metal (as is typical for a linear L-Au-Cl complex) with the largest values being associated with the complex where both phenyl rings are orthogonal with M-P-C-C torsion angles of $13.3^{\circ}$ and $9.9^{\circ}$.

\section{U.V.-vis. absorption properties}




\begin{tabular}{|c|c|c|c|c|}
\hline $\begin{array}{c}\text { Compoun } \\
\mathrm{d}\end{array}$ & $\lambda_{\mathrm{abs}} / \mathrm{nm}$ & $\lambda_{\mathrm{em}} / \mathrm{nm}$ & $\tau_{\mathrm{obs}} / \mathrm{ns}^{b}$ & $\phi$ \\
\hline L1 & $293,282,272,262,223$ & 339 & 6.5 & $-^{c}$ \\
\hline $\mathbf{L} 2$ & $375,344,328,314,300,276,266,242,235 \mathrm{sh}$ & 398,478 & 8.0 & $-^{c}$ \\
\hline L3 & $470,309,279,269,245,228 \mathrm{sh}$ & 571 & 1.0 & $-{ }^{c}$ \\
\hline$[\mathrm{AuCl}(\mathrm{L} 1)]$ & $291,282,272,223$ & 339 & 3.9 & $8 \%$ \\
\hline$[\mathrm{AuCl}(\mathrm{L} 2)]$ & $375,343,327,313,300,276,266,242,233$ & $377,397,417$ & 14.9 & $17 \%$ \\
\hline$[\mathrm{AuCl}(\mathbf{L} \mathbf{3})]$ & $442,298,270,241,224$ & 574 & 1.0 & $2 \%$ \\
\hline
\end{tabular}

a measurements obtained in MeCN solutions; ${ }^{b}$ using $\lambda_{\text {ex }} 295 \mathrm{~nm} ;{ }^{c}$ not determined due to potential air-sensitivity in solution.
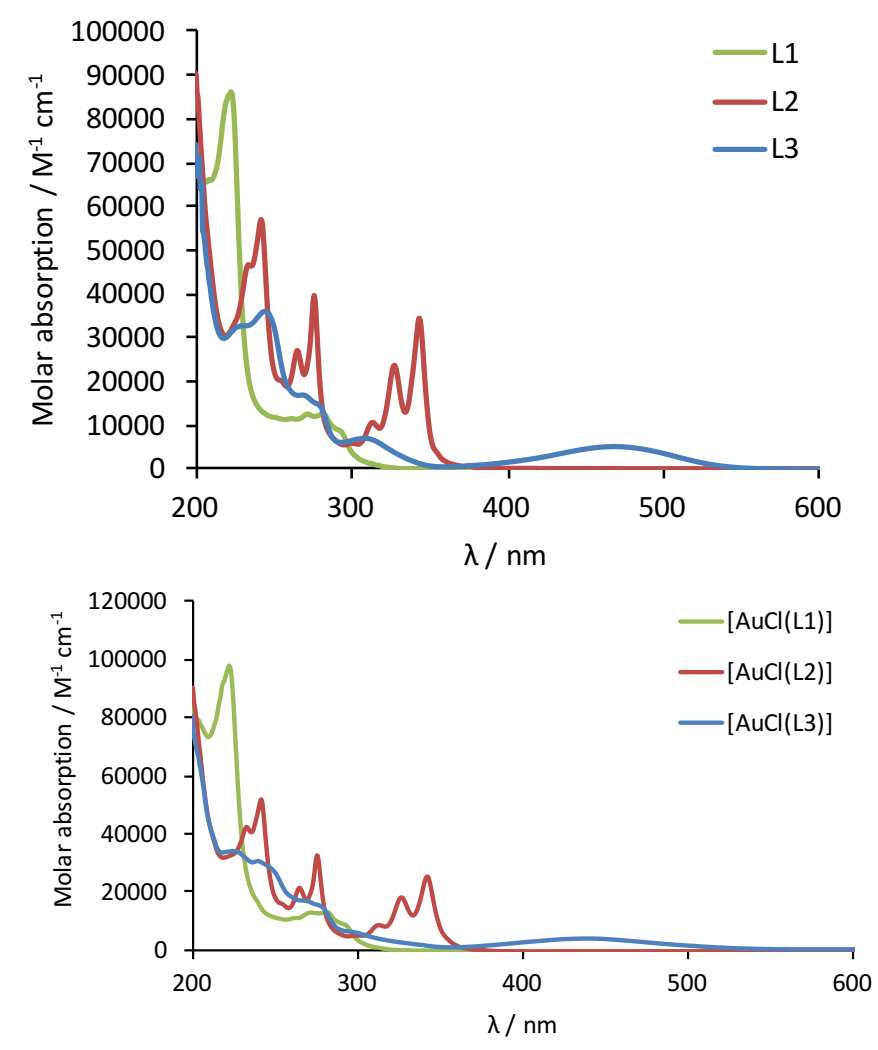

Figure 3. UV-vis. absorption spectra (recorded in $\mathrm{MeCN}$ ) for the ligands (top) and complexes (bottom).

Solution state (MeCN) UV-vis. absorption spectra were obtained for all ligands and complexes and the data is shown in Table 3. The spectra for the ligands are dominated by $\pi \rightarrow \pi^{*}$ absorbances (Figure 3) associated with the various aromatic units. The phenyl substituents contribute at the higher energies $(<260 \mathrm{~nm})$, while the naphthyl, pyrenyl and anthraquinone chromophores gave additional absorbances at progressively longer wavelengths. For $\mathbf{L} \mathbf{2}$, the 
spectrum revealed a vibronically structured appearance at $300-375 \mathrm{~nm}$, consistent with the various pyrene centred $\pi \rightarrow \pi^{*}$ transitions. In the case of the anthraquinone derivative $\mathbf{L} \mathbf{3}, \mathbf{a}$

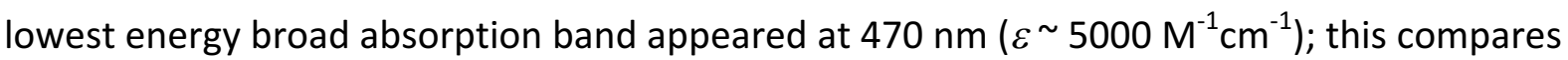
with $480 \mathrm{~nm}(\mathrm{MeOH})$ for 1-aminoanthraquinone. ${ }^{x i i}$ Amine-substituted anthraquinone derivatives are known to possess transitions that can be described as intramolecular charge transfer $(I C T)^{x x i i i}$ due to the donor-acceptor character of the chromophore. The precise positioning of the ICT band depends upon the nature and positioning of the substituent at the anthraquinone core. Therefore while the $470 \mathrm{~nm}$ band is ascribed to an ICT-type transition, it is one that may involve participation from the bonded $\mathrm{P}$ atom in the donor component (see later DFT discussion).

For the $A u(I)$ complexes the UV-vis. spectra (Figure 3) were dominated by the ligandcentred transitions discussed above, with minor perturbations observed as a consequence of coordination to $\mathrm{Au}(\mathrm{I})$. The case of $[\mathrm{AuCl}(\mathrm{L} 3)]$ is noteworthy, as it displays a hypsochromic shift of the ICT visible band upon coordination of $\mathrm{Au}(\mathrm{I})$. The shift is consistent with a reduction in the donor ability of the nitrogen atom at anthraquinone and rationalised by the direct conjugation of the gold atom to the anthraquinone unit via the P-N bond.

\section{Density Functional Theory}

The structures of $\mathbf{L 3}$ and $[\mathrm{AuCl}(\mathbf{L} \mathbf{3})]$ were computed using density functional calculations. Long-range corrected functionals such as CAM-B3LYP ${ }^{x \times i v}$ are often required for giving an adequate description of excited states with a significant chargetransfer component. ${ }^{x x v}$ In this case however, all the TD-DFT analyses (vide infra) gave excitation energies that were significantly higher in energy than those observed experimentally. After several functionals were screened, the M06 functional gave good agreement between experiment and theory, ${ }^{\mathrm{xxvi}}$ and was therefore used throughout. The SDD basis set, ${ }^{\mathrm{xxvii}}$ along with associated effective core potentials, was used for the Au atom, as is common practice for heavy transition metals; Dunning's correlation-consistent double- $\zeta$ basis set cc-pVDZ gave good results (for $C, H, O, N$ ) with reasonable computational cost, ${ }^{x x v i i i}$ although the $c c-p V(D+d) Z$ basis set was used for the third period elements, since this gives improved $d$-polarization compared to the 
original formulations, ${ }^{\text {xxix }}$ and is likely to be beneficial in coordination complexes bearing $\mathrm{P}$ and $\mathrm{Cl}$ donors.

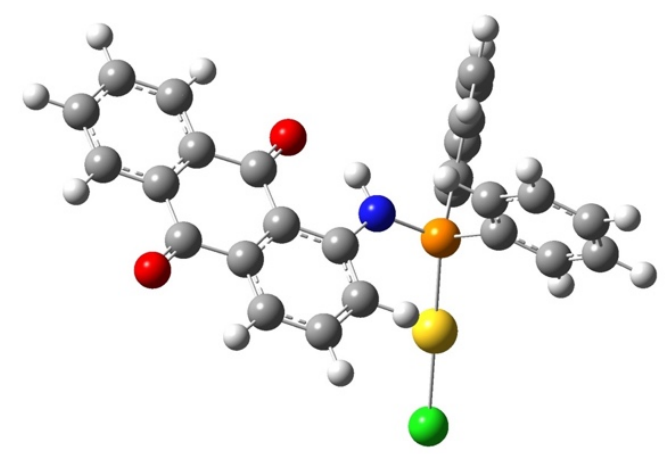

Figure 4. Calculated structure of $[\mathrm{AuCl}(\mathrm{L3})][\mathrm{MO6}-\mathrm{SDD} / \mathrm{cc}-\mathrm{pV}(\mathrm{D}+\mathrm{d}) \mathrm{Z} / \mathrm{cc}-\mathrm{pVDZ}]$

The calculated structure (optimised coordinates in ESI) of $[\mathrm{AuCl}(\mathrm{L3})]$ is shown in Figure 4 , and is in good agreement with that obtained from X-ray data. The Au-donor distances (see Table 3$)$ are slightly overestimated in the calculated structure $(\mathrm{Au}-\mathrm{Cl}$ : calculated $=2.356 \AA$, experimental $=2.2874(5) \AA$ and $2.2900(6) \AA$; Au-P: calculated $=2.296 \AA$, experimental $=$ 2.2225(6) $\AA$ and 2.2224(6) Å), whilst those within the ligand manifold are more accurately reproduced (e.g. P-N: calculated $=1.698 \AA$, experimental $=1.6774(19) \AA$ and 1.6851(19) $\AA$ ). The trigonal planar ( $s p^{2}$-hybridized) amine is well replicated by the calculations (sum of angles subtended at $\mathrm{N}$ : calculated $=358.2^{\circ}$, experimental $=360.0^{\circ}$ for both independent molecules in the asymmetric unit). The modest differences in bond distance are not thought to be significant in light of crystal packing forces and temperature effects (X-ray data were collected at $100 \mathrm{~K}$ ), and other properties pertaining to this complex were well-reproduced (vide infra).

The ${ }^{31} \mathrm{P}$ NMR shielding tensors were calculated to validate the observed experimental values; this is especially pertinent since there are few literature examples of this molecular fragment to give a reliable "expected" chemical shift range. As noted by Pellegrinet, ${ }^{x x, x x x i}$ the accuracy of such calculations can be improved by ensuring that a suitable reference molecule is chosen and calculated at the same level of theory. Given the structure of L3 (i.e. bearing two phenyl groups), $\mathrm{PPh}_{3}$ was used, and for which the experimental chemical shift is well established (-6 ppm). These calculations allowed the ${ }^{31} \mathrm{P}$ NMR chemical shifts (see Table 1 ) of $\mathbf{L 3}$ and $[\mathrm{AuCl}(\mathbf{L} \mathbf{3})]$ to be estimated as +26.8 and +49.9 ppm respectively, in good agreement with the experimental values of +26.1 and +55.8 ppm. 


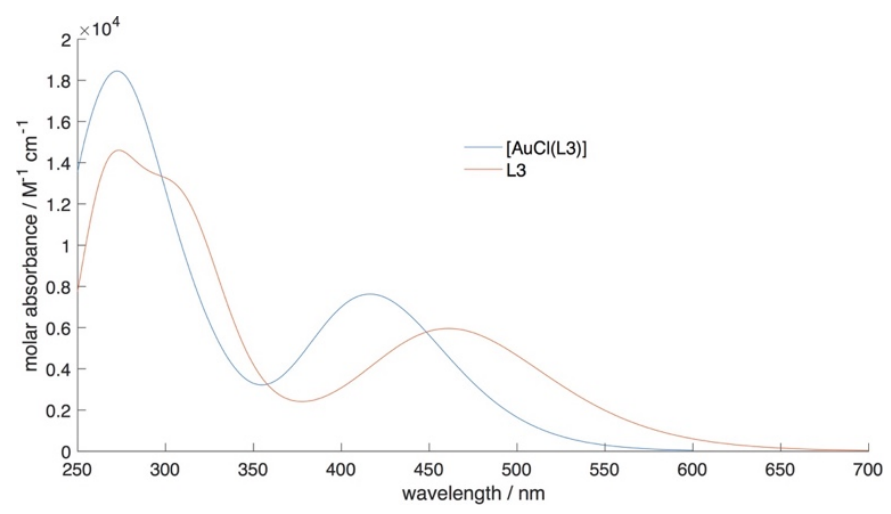

Figure 5. Simulated UV/vis absorption spectra of $\mathrm{L3}$ and $[\mathrm{AuCl}(\mathrm{L3})]$ [M06 - SDD/CC$p V(D+d) Z / c c-p V D Z]$

The underlying electronic basis of the observed differences in the absorption spectra for $\mathbf{L} \mathbf{3}$ and its $A u(I)$ complex was investigated using TD-DFT calculations. Simulated spectra, derived from the TD-DFT data, are shown in Figure 5, and represent a good agreement with those obtained experimentally. The principal area of interest is the low energy band between 400 and $500 \mathrm{~nm}$, which undergoes a significant blue-shift upon coordination to the $\mathrm{Au}(\mathrm{I})$ centre, as observed in the experimental data. As expected, the low energy bands correspond primarily to HOMO-LUMO transitions in both $\mathbf{L} 3$ and $[\mathrm{AuCl}(\mathrm{L3})]$ (Figures 6 and 7, respectively), and are dominated by significant $\pi-\pi^{*}$ character within the substituted anthraquinone. In addition, the HOMO of L3 contains appreciable orbital coefficients based upon the phosphorus and nitrogen atoms, effectively the $\mathrm{P}$ and $\mathrm{N}$ lone pairs, which gives the low energy transition a combination of $\pi-\pi^{*}, n(\mathrm{P})-\pi^{*}$, and $n(\mathrm{~N})-\pi^{*}$ character. The nitrogen orbital component is retained in the $\mathrm{HOMO}$ of $[\mathrm{AuCl}(\mathrm{LB})]$, but the phosphorus orbital character is decidedly altered, as expected, by virtue of coordination of the phosphorus atom to the $A u(I)$ centre; in $[\mathrm{AuCl}(\mathrm{L} \mathbf{3})]$ this component is encompassed in the Au-P $\sigma$-bond and thus $\sigma_{\mathrm{Au}-\mathrm{P}-\pi^{*}}$ character may also contribute to the HOMO-LUMO transition. Considering the energies of the orbitals involved, the energy of the LUMO is lowered very slightly upon Au coordination, from $-2.83 \mathrm{eV}$ in $\mathbf{L} 3$ to $-2.98 \mathrm{eV}$ in $[\mathrm{AuCl}(\mathbf{L} 3)]$, whereas the corresponding effect on the HOMO is much more pronounced, reducing the energy from $-6.29 \mathrm{eV}$ to $-6.80 \mathrm{eV}$. Thus, in effect, the observed blue shift in the absorption spectra is predicted upon lowering of the HOMO upon coordination of the $\mathrm{Au}(\mathrm{I})$ ion. All supporting data is included in the ESI. 


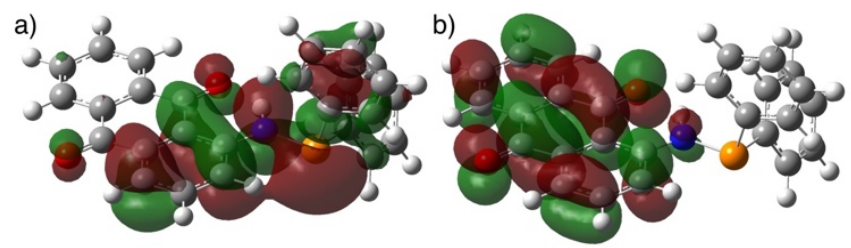

Figure 6. Calculated a) HOMO and b) LUMO of L3 [MO6 - SDD/cc-pV(D+d)Z/cc-pVDZ]

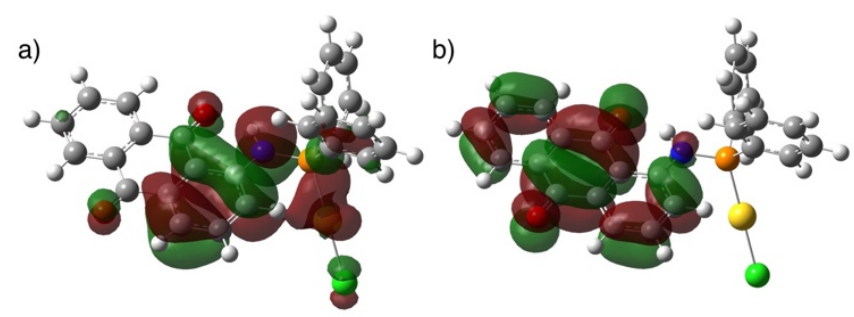

Figure 7. Calculated a) HOMO and b) LUMO of [AuCl(L3)] [MO6-SDD/cc-pV(D+d)Z/cc-pVDZ]

\section{Fluorescence Properties}

Each of the ligands was shown to be fluorescent (Figure 8) in aerated acetonitrile solution $\left(2.5 \times 10^{-5} \mathrm{M}\right)$, with emission wavelengths (Table 3 ) and profiles consistent with the presence of the organic fluorophore; as anticipated, the emission energy decreased across the series L1 (naphthyl) > L2 (pyrene) > L3 (anthraquinone). In the case of L2, the emission profile was composed of both structured monomer-type (350$425 \mathrm{~nm}$ ) and a broader feature at $475 \mathrm{~nm}$ which may be due to excimer-type emission. ${ }^{\text {xxii }}$ For $\mathbf{L} \mathbf{3}$, the visible emission peak at $c a .575 \mathrm{~nm}\left(\lambda_{\mathrm{ex}}=440 \mathrm{~nm}\right)$ was broad and structureless in appearance which is consistent with an emitting state of ICT character localised on the aminoanthraquinone moiety. Time-resolved measurements $\left(\lambda_{\mathrm{ex}}=295 \mathrm{~nm}\right)$ revealed observed lifetimes that were consistent with fluorescence emission in all cases (Table 3). The corresponding measurements on the complexes, using excitation wavelengths that correlate with the ligand-based absorption bands, revealed that the characteristic ligand-based fluorescence (Figure 8) was retained upon complexation to $\mathrm{Au}(\mathrm{I})$. For $[\mathrm{AuCl}(\mathbf{L 2})]$ the appearance of the emission profile was highly structured but with no evidence of excimer-type emission. The emission spectra 
of $\mathbf{L} 2$ and $[\mathrm{AuCl}(\mathbf{L} 2)]$ were obtained using identical concentration solutions $\left(2.5 \times 10^{-5}\right.$ $M)$, and therefore suggests that the presence of the coordinated $\{\mathrm{AuCl}\}$ unit may inhibit $\pi$ - $\pi$ stacking (the excimer band in $\mathbf{L} \mathbf{2}$ may be due to intramolecular interactions between the pyrene and phenyl groups within the ligand). $[\mathrm{AuCl}(\mathrm{L3})]$ again showed a visible region ICT-based fluorescence band which was subtly shifted, attributed to metal-based perturbation upon $\mathrm{Au}(\mathrm{I})$ coordination.
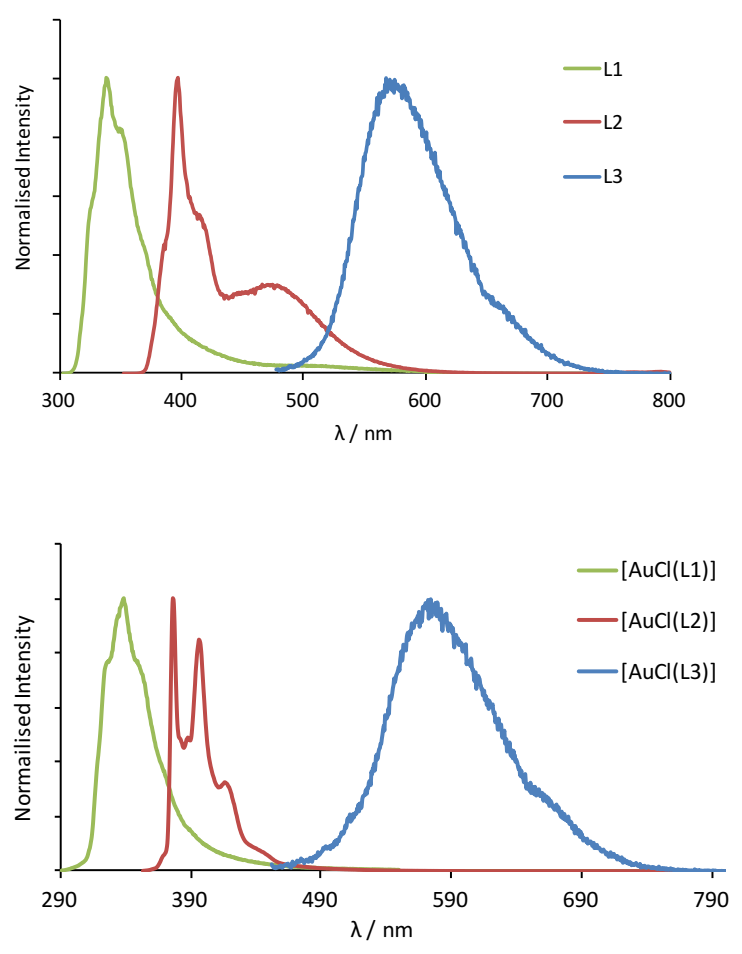

Figure 8. Steady state emission spectra (recorded in $\mathrm{MeCN}$ ) for the ligands (top) and complexes (bottom).

It is noteworthy that formation of the complexes led to variations in the recorded lifetimes, and in the case of $[\mathrm{AuCl}(\mathbf{L 2})]$ an extension to $\mathrm{ca} .15 \mathrm{~ns}$. This may indicate that the quenching of the pyrene fluorophore is inhibited by coordination to $\mathrm{Au}(\mathrm{I})$. In all cases the observed lifetimes suggest a ligand-centred emission which is fluorescent in nature. Quantum yields were obtained for the complexes using aerated solvent and determined to be $8 \%, 17 \%$, and $2 \%$ for $[\mathrm{AuCl}(\mathrm{L1}-3)]$, respectively. Therefore, the presence of the $\mathrm{Au}(\mathrm{I})$ heavy atom in these complexes does not ${ }^{\mathrm{xxxiii}}$ result in the observation of room temperature phosphorescence from ligand-centred states, unlike some other $\mathrm{Au}(\mathrm{I})$ phosphine complexes. ${ }^{\text {xxiv }}$ 


\section{Conclusions}

Fluorescent, functionalised aminophosphines can be synthesised straightforwardly and coordinated to $\mathrm{Au}(\mathrm{I})$ to give air stable complexes. Our examples show that naphthalene, pyrene or anthraquinone type fluorophores can be incorporated into aminophosphine ligand structures. The commercial availability of numerous other fluorescent amines suggests that a large number of fluorescent aminophosphine variants should be accessible. Supporting TDDFT calculations can reliably reproduce the structural features of the $A u(I)$ complexes. These theoretical approaches can also predict the excitation energies for the anthraquinone derivative and provide further validation via calculated ${ }^{31} \mathrm{P} N \mathrm{NM}$ chemical shifts. Our future studies will explore and expand the coordination chemistry of fluorescent aminophosphine ligands and investigate their viability and utility in a broad range of applications including bioimaging and catalysis.

\section{Experimental}

\section{General Considerations}

All reagents and solvents were commercially available and were used without further purification if not stated otherwise. For the measurement of ${ }^{1} \mathrm{H},{ }^{31} \mathrm{P}$, and ${ }^{13} \mathrm{C} N M R$ spectra a Bruker Fourier ${ }^{300}$ (300 MHz), Bruker AVANCE HD III equipped with a BFFO SmartProbe ${ }^{\mathrm{TM}}(400 \mathrm{MHz})$ or Bruker AVANCE III HD with BBO Prodigy CryoProbe (500 MHz) was used. The obtained chemical shifts $\delta$ are reported in ppm and are referenced to the residual solvent signal. Spin-spin coupling constants $J$ are given in $\mathrm{Hz}$.

Low-resolution mass spectra were obtained by the staff at Cardiff University. High-resolution mass spectra were carried out at the EPSRC National Mass Spectrometry Facility at Swansea University. High resolution mass spectral (HRMS) data were obtained on a Waters MALDI-TOF $m x$ at Cardiff University or on a Thermo Scientific LTQ Orbitrap XL by the EPSRC UK National Mass Spectrometry Facility at Swansea University. IR spectra were obtained from a Shimadzu IR-Affinity-1S FTIR. 
Reference to spectroscopic data are given for known compounds. UV-Vis studies were performed on a Shimadzu UV-1800 spectrophotometer as MeCN solutions (2.5 or $5 \times$ $\left.10^{-5} \mathrm{M}\right)$. Photophysical data were obtained on a JobinYvon-Horiba Fluorolog spectrometer fitted with a JY TBX picosecond photodetection module as MeCN solutions. Quantum yield measurements were obtained on aerated MeCN solutions of the complexes using $\left[\mathrm{Ru}(\mathrm{bpy})_{3}\right]\left(\mathrm{PF}_{6}\right)_{2}$ in aerated $\mathrm{MeCN}$ as a standard $(\Phi=0.016) .{ }^{\mathrm{xx} \times \mathrm{v}}$ Emission spectra were uncorrected and excitation spectra were instrument corrected. The pulsed source was a Nano-LED configured for $295 \mathrm{~nm}$ (L1, L2) or $459 \mathrm{~nm}$ (L3) output operating at $1 \mathrm{MHz}$. Luminescence lifetime profiles were obtained using the JobinYvon-Horiba FluoroHub single photon counting module and the data fits yielded the lifetime values using the provided DAS6 deconvolution software.

\section{X-ray Diffraction}

A suitable crystal was selected ${ }^{\mathrm{xxxvi}}$ and mounted on a MITIGEN holder in perfluoroether oil on a Rigaku FRE+ equipped with HF Varimax confocal mirrors and an AFC12 goniometer and HG Saturn 724+ detector diffractometer. The crystal was kept at $T=$ 100(2) K during data collection. Data were measured using profile data from $\omega$-scans using $\mathrm{MoK}_{\alpha}$ radiation. Cell determination, data collection, reduction and absorption

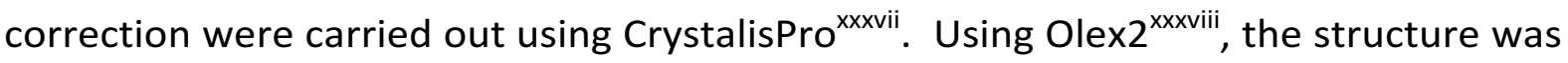
solved by charge flipping using SUPERFLIP ${ }^{\mathrm{xxxix}}$ and the models were refined with version 2014/7 of ShelXL ${ }^{\mathrm{Xl}}$ using Least Squares minimisation with all non-H atoms refined anisotropically. Hydrogen atom positions were calculated geometrically and refined using the riding model.

Crystal Data for [AuCl(L3)]: $\mathrm{C}_{26} \mathrm{H}_{18} \mathrm{AuClNO}_{2} \mathrm{P}, \mathrm{M}_{r}=639.80$, triclinic, $P-1$ (No. 2), $\mathrm{a}=$ $9.23605(10) \AA, b=14.82932(17) \AA, c=16.64944(19) \AA, \alpha=90.9323(9)^{\circ}, b=$ 101.3732(9) $, V=94.2899(9)^{\circ}, V=2228.21(4) \AA^{3}, T=100(2) \mathrm{K}, Z=4, Z^{\prime}=2, \mu\left(\mathrm{MoK}_{\alpha}\right)=$ $6.819,60900$ reflections measured, 10204 unique $\left(R_{\text {int }}=0.0335\right)$ which were used in all calculations. The final $w R_{2}$ was 0.0399 (all data) and $R_{1}$ was $0.0176(I>2(I))$. 


\section{Density functional calculations}

Calculations were undertaken using the Gaussian 09 program, ${ }^{x l i}$ using the M06 hybrid functional, ${ }^{x x v i}$ employing the quasi-relativistic $S D^{x \times v i i}$ effective core potential along with associated basis set for $A u, c c-p V(D+d) Z$ for $C l$ and $P$, ${ }^{x i x}$ and $c c-p V D Z^{x x v i i i}$ on all remaining centres. Geometry optimizations were carried out without symmetry restraints, and the nature of the stationary points (minimum or saddle point) verified by calculating the vibrational frequencies. The NMR shielding tensors were calculated using the gauge-including atomic orbital (GIAO) method. ${ }^{\text {xlii,xliii }}$ Chemical shifts are given relative to $\mathrm{PPh}_{3}$ calculated at the same level of theory, and calibrated against the experimental chemical shift in $\mathrm{CDCl}_{3}(\delta=-6.0 \mathrm{ppm})$. TD-DFT calculations were carried out using the unrestricted M06 functional, with the same basis sets detailed above. The first 20 excited states were calculated; details of all excited states are included in the ESI. Solvent interactions can be crucial for accurately reproducing experimental data; ${ }^{x \times v}$ solvent was therefore modelled using the polarizable continuum model, with the molecular cavity defined by a united atom model that incorporates hydrogen into the parent heavy atoms, and included in all calculations. ${ }^{\text {xliv }}$ Geometries were optimized separately in each solvent employed (acetonitrile for TD-DFT and chloroform for NMR shielding tensors) and displayed no significant differences in metric parameters.

\section{Preparation of aminophosphine ligands}

\section{Synthesis of $L 1$}

1-Naphthalenemethylamine $(0.17 \mathrm{ml}, 1.4 \mathrm{mmol})$ and triethylamine $(0.19 \mathrm{ml}, 1.4 \mathrm{mmol})$ were dissolved in deaerated dichloromethane $(10 \mathrm{ml})$ under a nitrogen atmosphere. Diphenylchlorophosphine $(0.21 \mathrm{ml}, 1.4 \mathrm{mmol})$ in dicloromethane $(10 \mathrm{ml})$ was added dropwise at $0{ }^{\circ} \mathrm{C}$ over 10 minutes. The resulting solution was stirred at room temperature for 2 hours. The solution was then washed with deaerated water $(20 \mathrm{ml})$, dried over $\mathrm{MgSO}_{4}$ and the solvent removed in vacuo to give L1 as a colourless oil (463 $\mathrm{mg}, 97 \%) .{ }^{1} \mathrm{H}$ NMR $\left(400 \mathrm{MHz}, \mathrm{CDCl}_{3}\right): \delta_{\mathrm{H}} 7.91-7.87(\mathrm{~m}, 1 \mathrm{H}), 7.77\left(\mathrm{dd}, J_{\mathrm{HH}}=6.8,2.8 \mathrm{~Hz}\right.$, $1 \mathrm{H}), 7.67\left(\mathrm{~d},{ }^{3} \mathrm{~J}_{\mathrm{HH}}=7.8 \mathrm{~Hz}, 1 \mathrm{H}\right), 7.43-7.34(\mathrm{~m}, 7 \mathrm{H}), 7.34-7.24(\mathrm{~m}, 7 \mathrm{H}), 4.44$ (app. ${ }^{3}{ }^{3} \mathrm{JHH}_{\mathrm{H}}$ $\left.=6.7 \mathrm{~Hz}, 2 \mathrm{H}, \mathrm{CH}_{2}\right), 2.25-2.16(\mathrm{~m}, 1 \mathrm{H}, \mathrm{NH}) \mathrm{ppm} .{ }^{13} \mathrm{C}\left\{{ }^{1} \mathrm{H}\right\} \mathrm{NMR}\left(101 \mathrm{MHz}, \mathrm{CDCl}_{3}\right): \delta_{\mathrm{C}}$ 
$141.2\left(\mathrm{~d}, J_{\mathrm{CP}}=12.5 \mathrm{~Hz}\right), 137.1\left(\mathrm{~d}, J_{\mathrm{CP}}=8.1 \mathrm{~Hz}\right), 134.0,132.3,132.2,131.7,131.5,129.0$, $128.8,128.7,128.5,128.4,128.0,126.2,125.8,125.7,125.6,123.9,123.3,48.1$ (d, J $J_{C P}$ $=16.3 \mathrm{~Hz}) \mathrm{ppm} .{ }^{31} \mathrm{P}\left\{{ }^{1} \mathrm{H}\right\} \mathrm{NMR}\left(162 \mathrm{MHz}, \mathrm{CDCl}_{3}\right): \delta_{\mathrm{P}}+42.19 \mathrm{ppm}$. HRMS found $\mathrm{m} / \mathrm{z}$ 342.1400, calcd $\mathrm{m} / z 342.1412$ for $\left[\mathrm{C}_{23} \mathrm{H}_{20} \mathrm{NP}\right]^{+}$. UV-vis. (MeCN) $\lambda_{\max }\left(\varepsilon / \mathrm{dm}^{3} \mathrm{~mol}^{-1} \mathrm{~cm}^{-1}\right)$ : 293 (8520), 282 (12520), 272 (12360), 262, (11280), 223 (86480) nm. IR (solid) v / cm ${ }^{1}$ : 3399, 3243, 3049, 1595, 1581, 1508, 1477, 1431, 1390, 1321, 1311, 1261, 1167, 1094, 1082, 1061, 1026, 997, 970, 910, 883, 858, 839, 794, 769, 740, 711, 634, 617, $594,552,521,507,488,469,444,420,413$.

\section{Synthesis of $L 2$}

As with L1, but using 1-pyrenemethylamine $(487 \mathrm{mg}, 2.1 \mathrm{mmol})$, triethylamine $(0.33$ $\mathrm{ml}, 2.5 \mathrm{mmol})$, diphenylchlorophosphine $(0.38 \mathrm{ml}, 2.1 \mathrm{mmol})$ and dichloromethane (20 $\mathrm{ml}$ ) to give $\mathrm{L} 2$ as a yellow oil $(808 \mathrm{mg}, 93 \%) .{ }^{1} \mathrm{H} N M R\left(400 \mathrm{MHz}, \mathrm{CDCl}_{3}\right): \delta_{\mathrm{H}} 8.14-8.06$ $(\mathrm{m}, 2 \mathrm{H}), 8.02-7.83(\mathrm{~m}, 7 \mathrm{H}), 7.69\left(\mathrm{dd}, J_{H H}=11.1,7.6 \mathrm{~Hz}, 1 \mathrm{H}\right), 7.50$ (app. t, $J_{\mathrm{HH}}=7.9 \mathrm{~Hz}$, $1 \mathrm{H}), 7.45-7.39(\mathrm{~m}, 5 \mathrm{H}), 7.28\left(\mathrm{~d},{ }^{3} J_{H H}=5.1 \mathrm{~Hz}, 2 \mathrm{H}\right), 7.18-7.13(\mathrm{~m}, 1 \mathrm{H}), 4.67$ (app. $t$, $\left.{ }^{3} J_{\mathrm{HH}}=6.6 \mathrm{~Hz}, 2 \mathrm{H}, \mathrm{CH}_{2}\right), 2.34-2.26(\mathrm{~m}, 1 \mathrm{H}, \mathrm{NH}) \mathrm{ppm} .{ }^{13} \mathrm{C}\left\{{ }^{1} \mathrm{H}\right\} \mathrm{NMR}\left(101 \mathrm{MHz}, \mathrm{CDCl}_{3}\right): \delta_{\mathrm{C}}$ $141.2\left(\mathrm{~d}, J_{\mathrm{CP}}=12.5 \mathrm{~Hz}\right), 135.5\left(\mathrm{~d}, J_{\mathrm{CP}}=7.1 \mathrm{~Hz}\right), 135.3\left(\mathrm{~d}, J_{\mathrm{CP}}=7.1 \mathrm{~Hz}\right), 134.9\left(\mathrm{~d}, J_{\mathrm{CP}}=8.0\right.$ Hz), 131.7, 131.5, 131.4, 130.9 (d, J = 7.9 Hz), 129.7, 129.0, 128.8, 128.7, 128.6, 128.4 (d, $J=6.2 \mathrm{~Hz}$ ), 127.7, 127.6, 127.5, 126.7, 126.0, 125.2, 125.1, 125.0, 124.9, 123.4, 48.3 $\left(\mathrm{d}, J_{\mathrm{CP}}=15.8 \mathrm{~Hz}\right) \mathrm{ppm} .{ }^{31} \mathrm{P}\left\{{ }^{1} \mathrm{H}\right\} \mathrm{NMR}\left(202 \mathrm{MHz}, \mathrm{CHCl}_{3}\right): \delta_{\mathrm{P}}+42.12 \mathrm{ppm}$. HRMS found $\mathrm{m} / z$ 415.1484, calcd $m / z 415.1490$ for $\left[\mathrm{C}_{29} \mathrm{H}_{22} \mathrm{NP}\right]^{+}$. UV-vis. (MeCN) $\lambda_{\max }\left(\varepsilon / \mathrm{dm}^{3} \mathrm{~mol}^{-1} \mathrm{~cm}^{-1}\right)$ : 375 (920), 344 (34480), 328 (23800), 314 (10800), 300 (6040), 276 (39680), 266 (27120), 242 (56960), $235 \mathrm{sh}$ (46440) nm. IR (solid) $v / \mathrm{cm}^{-1}:$ 3044, 2963, 2857, 1601, $1585,1477,1431,1414,1391,1342,1306,1261,1179,1173,1159,1088,1067,1026$, 997, 968, 912, 893, 841, 816, 739, 719, 692, 617,586, 555, 513, 419, 409, 401.

\section{Synthesis of $L 3$}

As for L1, but using 1-aminoanthraquinone $(1 \mathrm{~g}, 4.6 \mathrm{mmol})$, triethylamine $(0.74 \mathrm{ml}, 5.5$ $\mathrm{mmol})$, diphenylchlorophosphine $(0.85 \mathrm{mmol}, 4.6 \mathrm{mmol})$ and dichloromethane $(30 \mathrm{ml})$ to give $\mathrm{L} 3$ as a dark orange solid (583 mg, $64 \%) .{ }^{1} \mathrm{H}$ NMR $\left(500 \mathrm{MHz}, \mathrm{CDCl}_{3}\right): \delta_{\mathrm{H}} 10.36$ $\left(\mathrm{d},{ }^{2} J_{\mathrm{HP}}=7.3 \mathrm{~Hz}, 1 \mathrm{H}, \mathrm{NH}\right), 8.17-8.08(\mathrm{~m}, 2 \mathrm{H}), 7.87-7.80(\mathrm{~m}, 1 \mathrm{H}), 7.67-7.57(\mathrm{~m}, 5 \mathrm{H})$, 7.47-7.39 (m, 6H), 7.29-7.26 (m, 2H), $7.12(\mathrm{~s}, 1 \mathrm{H}) \mathrm{ppm} .{ }^{13} \mathrm{C}\left\{{ }^{1} \mathrm{H}\right\} \mathrm{NMR}\left(126 \mathrm{MHz}, \mathrm{CDCl}_{3}\right)$ : 
$\delta_{C} 186.4(\mathrm{C}=0), 183.5(\mathrm{C}=0), 152.5,152.3,139.0,138.9,135.3,135.2,134.7,134.6$, $134.2,133.6,133.1,131.5$ (d, $\left.J_{\mathrm{CP}}=21.3 \mathrm{~Hz}\right), 129.7,128.9\left(\mathrm{~d}, J_{\mathrm{CP}}=7.1 \mathrm{~Hz}\right), 127.0$ (d, $J_{\mathrm{CP}}$ $=16.9 \mathrm{~Hz}), 126.9,123.3,122.8,122.6,118.5,117.4,116.1 \mathrm{ppm} .{ }^{31} \mathrm{P}\left\{{ }^{1} \mathrm{H}\right\} \mathrm{NMR}(162 \mathrm{MHz}$, $\left.\mathrm{CHCl}_{3}\right): \delta_{\mathrm{P}}+26.11$ ppm. UV-vis. (MeCN) $\lambda_{\max }\left(\varepsilon / \mathrm{dm}^{3} \mathrm{~mol}^{-1} \mathrm{~cm}^{-1}\right): 470$ (4880), 309 (7880), 279 (16160), 269 (18120), 245 (36720), 228 sh (32720) nm. HRMS found $m / z$ 408.1167, calcd $m / z 408.1153$ for $\left[\mathrm{C}_{26} \mathrm{H}_{19} \mathrm{~N}_{2} \mathrm{OP}\right]^{+}$. IR (solid) $v / \mathrm{cm}^{-1}$ : 3167, 3051, 1668, 1630, $1593,1570,1431,1396,1346,1300,1253,1231,1169,1092,1070,1040,1018,997$, $912,893,831,806,775,748,735,704,692,602,546,513,476,436,420$.

\section{Preparation of aminophosphine complexes}

Synthesis of $[\mathrm{AuCl}(\mathrm{L1})]$

L1 (111 $\mathrm{mg}, 0.32 \mathrm{mmol}$ ) and tetrahydrothiophenegold chloride (94 $\mathrm{mg}, 0.29 \mathrm{mmol}$ ) were added to degassed dichloromethane $(20 \mathrm{ml})$ and the solution stirred at room temperature under nitrogen for 1.5 hours. The solvent was reduced in vacuo and hexane added dropwise. The mother liquor was decanted to leave $[\mathrm{AuCl}(\mathrm{L} 1)]$ as a grey solid (35 mg, $21 \%$ ). ${ }^{1} \mathrm{H}$ NMR $\left(400 \mathrm{MHz}, \mathrm{CDCl}_{3}\right): \delta_{\mathrm{H}} 7.96\left(\mathrm{~d},{ }^{3} J_{\mathrm{HH}}=7.9 \mathrm{~Hz}, 1 \mathrm{H}\right), 7.87(\mathrm{~d}$, $\left.{ }^{3} J_{\mathrm{HH}}=8.4 \mathrm{~Hz}, 1 \mathrm{H}\right), 7.79\left(\mathrm{~d},{ }^{3} J_{\mathrm{HH}}=8.2 \mathrm{~Hz}, 1 \mathrm{H}\right), 7.67\left(\mathrm{~d},{ }^{3} J_{\mathrm{HH}}=7.5 \mathrm{~Hz}, 2 \mathrm{H}\right), 7.64\left(\mathrm{~d},{ }^{3} J_{\mathrm{HH}}=\right.$ $7.4 \mathrm{~Hz}, 2 \mathrm{H}), 7.54-7.48(\mathrm{~m}, 4 \mathrm{H}), 7.48-7.42(\mathrm{~m}, 5 \mathrm{H}), 7.42-7.36(\mathrm{~m}, 1 \mathrm{H}), 4.71-4.64(\mathrm{~m}$, $2 \mathrm{H})$ ppm. ${ }^{13} \mathrm{C}\left\{{ }^{1} \mathrm{H}\right\}$ NMR $\left(101 \mathrm{MHz}, \mathrm{CDCl}_{3}\right): \delta_{\mathrm{C}} 134.1,132.7,132.6,132.4,132.3,131.8$, $131.2,129.3,129.2,129.1,129.0,126.8,126.7,126.2,125.5,123.4,47.9$ ppm. ${ }^{31} \mathrm{P}\left\{{ }^{1} \mathrm{H}\right\}$

NMR (162 MHz, CDCl 3 ): $\delta_{\mathrm{p}}+64.58$ ppm. UV-vis. (MeCN) $\lambda_{\max }\left(\varepsilon / \mathrm{dm}^{3} \mathrm{~mol}^{-1} \mathrm{~cm}^{-1}\right): 291$ (9080), 282 (13160), 272 (12920), 223 (97680) nm. HRMS found m/z 572.0629, calcd $\mathrm{m} / z 572.0609$ for $\left[\mathrm{C}_{23} \mathrm{H}_{20} \mathrm{AuCINP}\right]^{-}$. IR (solid) $v / \mathrm{cm}^{-1}: 3248,3207,3049,2359,1595$, $1576,1555,1508,1499,1476,1460,1435,1395,1379,1306,1265,1248,1180,1167$, 1105, 1063, 1041, 1026, 995, 962, 881, 854, 800, 789, 770, 745, 714, 691, 619.

\section{Synthesis of $[\mathrm{AuCl}(\mathrm{L2})]$}

L2 (267 mg, $0.64 \mathrm{mmol}$ ) and tetrahydrothiophenegold chloride (187 mg, 0. $58 \mathrm{mmol}$ ) were added to degassed dichloromethane $(20 \mathrm{ml})$ and the solution stirred at room temperature under nitrogen for 2 hours. The solvent was reduced in vacuo and diethyl 
ether added dropwise. The resultant precipitate was filtered and dried to yield $[\mathrm{AuCl}(\mathrm{L} 2)]$ as a pale yellow solid (50 mg, $13 \%) .{ }^{1} \mathrm{H} \mathrm{NMR}\left(500 \mathrm{MHz}, \mathrm{CDCl}_{3}\right): \delta_{\mathrm{H}} 8.15-$ $8.10(\mathrm{~m}, 3 \mathrm{H}), 8.05\left(\mathrm{~d},{ }^{3} \mathrm{~J}_{H H}=9.2 \mathrm{~Hz}, 1 \mathrm{H}\right), 7.99\left(\mathrm{~d},{ }^{3} J_{\mathrm{HH}}=8.9 \mathrm{~Hz}, 1 \mathrm{H}\right), 7.95(\mathrm{~s}, 1 \mathrm{H}), 7.87(\mathrm{~d}$, $\left.{ }^{3} J_{H H}=7.7 \mathrm{~Hz}, 1 \mathrm{H}\right), 7.74\left(\mathrm{dd}, J_{\mathrm{HH}}=13.9,7.1 \mathrm{~Hz}, 2 \mathrm{H}\right), 7.62-7.56(\mathrm{~m}, 4 \mathrm{H}), 7.41-7.37(\mathrm{dd}$, $\left.J_{\mathrm{HH}}=7.4,1.8 \mathrm{~Hz}, 1 \mathrm{H}\right), 7.36-7.31(\mathrm{~m}, 3 \mathrm{H}), 7.23$ (app. $\left.\mathrm{t}, J_{\mathrm{HH}}=7.2 \mathrm{~Hz}, 2 \mathrm{H}\right), 4.83\left(\mathrm{dd}, J_{\mathrm{HH}}=\right.$ 8.8, $6.4 \mathrm{~Hz}, 1 \mathrm{H}), 2.75$ (br. s, $1 \mathrm{H}, \mathrm{NH}) \mathrm{ppm} .{ }^{13} \mathrm{C}\left\{{ }^{1} \mathrm{H}\right\} \mathrm{NMR}\left(101 \mathrm{MHz}, \mathrm{CDCl}_{3}\right): \delta_{\mathrm{C}}$ 134.3, $133.1,132.7,132.5,132.3,132.2$, 131.4, 130.8, 129.4, 129.3, 129.2, 128.9, 128.6, $128.0,127.9$, 127.8, 127.5, 127.2, 126.3, 125.7, 125.6, 125.0, 124.9, 124.8, 122.8, 122.7, 119.8, 48.2 ppm. ${ }^{31} \mathrm{P}\left\{{ }^{1} \mathrm{H}\right\}$ NMR (202 MHz, $\left.\mathrm{CDCl}_{3}\right): \delta_{\mathrm{P}}+64.72 \mathrm{ppm}$. UV-vis. (MeCN) $\lambda_{\max }\left(\varepsilon / \mathrm{dm}^{3} \mathrm{~mol}^{-1} \mathrm{~cm}^{-1}\right): 375$ (200), 343 (25280), 327 (18120), 313 (8640), 300 (5080), 276 (32480), 266 (21240), 242 (51680), 233 (42280) nm. HRMS found $m / z$ 612.1143, calcd $m / z 612.1150$ for $\left[\mathrm{C}_{29} \mathrm{H}_{22} \mathrm{AuNP}\right]^{+}$. IR (solid) $\mathrm{v} / \mathrm{cm}^{-1}: 3379,3036,2363,1605,1587$, $1553,1504,1499,1477,1435,1418,1395,1375,1304,1240,1180,1169,1130,1101$, 1067, 1049, 1022, 995, 961, 920, 903, 878, 843, 825, 820, 808, 746, 723, 710, 692, 619.

\section{Synthesis of $[\mathrm{AuCl}(\mathrm{LB})]$}

L3 (130 $\mathrm{mg}, 0.32 \mathrm{mmol}$ ) and tetrahydrothiophenegold chloride (93 $\mathrm{mg}, 0.29 \mathrm{mmol}$ ) were added to degassed dichloromethane $(15 \mathrm{ml})$ and the solution stirred at room temperature under nitrogen for 2 hours. The solvent was reduced in vacuo and diethyl ether added dropwise. The resultant precipitate was filtered and dried to give a crude solid. This was then purified by column chromatography (silica) and eluted as the first fraction from 9:1 DCM:MeOH, to give $[\mathrm{AuCl}(\mathrm{L} 3)]$ as an orange solid (13 $\mathrm{mg}, 19 \%) .{ }^{1} \mathrm{H}$ $\operatorname{NMR}\left(500 \mathrm{MHz}, \mathrm{CDCl}_{3}\right): \delta_{\mathrm{H}} 10.92\left(\mathrm{~d},{ }^{2} J_{\mathrm{HP}}=6.1 \mathrm{~Hz}, 1 \mathrm{H}, \mathrm{NH}\right), 8.31-8.24(\mathrm{~m}, 2 \mathrm{H}), 7.95(\mathrm{~d}$, $\left.{ }^{3} J_{H H}=7.4 \mathrm{~Hz}, 1 \mathrm{H}\right), 7.89-7.83(\mathrm{~m}, 4 \mathrm{H}), 7.80\left(\mathrm{dd}, J_{\mathrm{HH}}=5.9,2.1 \mathrm{~Hz}, 2 \mathrm{H}\right), 7.67\left(\mathrm{~d}, J_{\mathrm{HH}}=8.0\right.$ $\mathrm{Hz}, 1 \mathrm{H}), 7.64-7.60(\mathrm{~m}, 3 \mathrm{H}), 7.60-7.55(\mathrm{~m}, 4 \mathrm{H}) \mathrm{ppm} .{ }^{13} \mathrm{C}\left\{{ }^{1} \mathrm{H}\right\}$ NMR $\left(126 \mathrm{MHz}, \mathrm{CDCl}_{3}\right)$ : $\delta_{C} 187.5,182.7,146.6,135.9,134.7,134.6,134.5,134.1,133.2,133.1,132.7,132.6$ (d, $J=16.1 \mathrm{~Hz}) 130.3,129.8(\mathrm{~d}, J=12.7 \mathrm{~Hz}), 127.3,122.8(\mathrm{~d}, J=13.8 \mathrm{~Hz}), 121.0,118.0$, $117.9 \mathrm{ppm} .{ }^{31} \mathrm{P}\left\{{ }^{1} \mathrm{H}\right\}$ NMR $\left(162 \mathrm{MHz}, \mathrm{CDCl}_{3}\right): \delta_{\mathrm{P}}+55.77 \mathrm{ppm}$. HRMS found $\mathrm{m} / z$ 604.0791, calcd $m / z 604.0735$ for $\left[\mathrm{C}_{26} \mathrm{H}_{18} \mathrm{AuClNO}_{2} \mathrm{P}+\mathrm{Cl}\right]^{+}$. UV-vis. (MeCN) $\lambda_{\max }\left(\varepsilon / \mathrm{dm}^{3} \mathrm{~mol}^{-1} \mathrm{~cm}^{-1}\right)$ : 442 (3720), 298 (6040), 270 (16560), 241 (30240), 224 (33760) nm. IR (solid) v/ cm ${ }^{-1}$ $3410,3306,3042,2976,2587,2496,2374,1165,1632,1585,1543,1472,1460,1435$, 
$1396,1344,1265,1298,1233,1171,1159,1105,1042,1022,997,829,802,777,748$, $735,695,640,606$.

\section{Acknowledgements}

We thank the staff of the EPSRC Mass Spectrometry National Service (Swansea University) and the National Crystallographic Service at the University of Southampton. Access to the Cardiff University high performance computing facility "ARCCA" is gratefully acknowledged.

\section{Notes and references}

¥CDC reference number 1571819 contains the supplementary crystallographic data for this paper. These data can be obtained free of charge from the Cambridge Crystallographic Data Centre via www.ccdc.cam.ac.uk/data_request/cif.

\footnotetext{
'M. Alajarin, C. Lopez-Leonardo, P. Llamas-Lorente, Top Curr. Chem., 2005, 250, 77.

ii J. Gopalakrishnan, Appl. Organomet. Chem., 2009, 23, 291

iii For example: T.Q. Ly, A.M.Z. Slawin, J.D. Woollins, J. Chem. Soc., Dalton Trans., 1997, 1611; S.M. Aucott, A.M.Z. Slawin, J.D. Woollins, Eur. J. Inorg. Chem., 2002, 2408.

iv For example: A.D. Burrows, M.F. Mahon, M.T. Palmer, J. Chem. Soc., Dalton Trans., 2000, 3615; S. Naik, S. Kumar, J.T. Mague, M.S. Balakrishna, Dalton Trans., 2016, 45, 18434; L. Baiget, A.S. Batsanov, P.W. Dyer, M.A. Fox, M.J. Hanton, J.A.K. Howard, P.K. Lane, S.A. Solomon, Dalton Trans., 2008, 1043; P.W. Dyer, J. Fawcett, M.J. Hanton, J. Organomet. Chem., 2005, 690, 5264; P.W. Dyer, J. Fawcett, M.J. Hanton, Organometallics, 2008, 27, 5082; F. Majoumo-Mbe, P. Lonnecke, E. Hey-Hawkins, Z. Anorg. Allg. Chem., 2008, 634, 2385.

v M.L. Clarke, D.J. Cole-Hamilton, J.D. Woollins, J. Chem. Soc., Dalton Trans., 2001, 2721

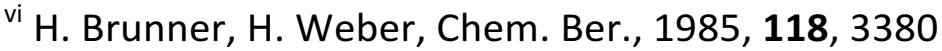

vii X. Chen, R. Guo, Y. Li, G. Chen, C-H. Yeung, A.S.C. Chan, Tetrahedron: Asymmetry, 2004, 15, 213.

viii S. Nieto, C. Cativiela, E.P. Urriolabeitia, New J. Chem., 2012, 36, 566.
} 
${ }^{i x}$ L.A. Mullice, F.L. Thorp-Greenwood, R.H. Laye, M.P. Coogan, B.M. Kariuki, S.J.A. Pope, Dalton Trans., 2009, 6836; L.A. Mullice, H.J. Mottram, A.J. Hallett, S.J.A. Pope, Eur. J. Inorg. Chem., 2012, 3054; E.E. Langdon-Jones, D. Lloyd, A.J. Hayes, S.D. Wainwright, H.J. Mottram, S.J. Coles, P.N. Horton, S.J.A. Pope, Inorg. Chem., 2015, 54, 6606; E.E. LangdonJones, S.J.A. Pope, Chem. Commun., 2014, 50, 10343; R.G. Balasingham, C.F. Williams, H.J. Mottram, M.P. Coogan, S.J.A. Pope, Organometallics, 2012, 31, 5835.

${ }^{x}$ F-B. Xu, L-H. Weng, L-J. Sun, Z-Z. Zhang, Organometallics, 2000, 19, 2658; F-B. Xu, Q-S. Li, L-Z. Wu, X-B. Leng, Z-C. Li, X-S. Zeng, Y.L. Chow, Z-Z. Zhang, Organometallics, 2003, 22, 633; Q-S. Li, C-Q. Wan, R-Y. Zou, F-B. Xu, H-B. Song, X-J. Wan, Z-Z. Zhang, Inorg. Chem., 2006, 45, 1888.

${ }^{x i}$ L.H. Davies, B. Stewart, R.W. Harrington, W. Clegg, L.J. Higham, Angew. Chemie Int. Ed., 2012, 124, 5005.

xii S. Nigam, B.P. Burke, L.H. Davies, J. Domarkas, J.F. Wallis, P.G. Waddell, J.S. Waby, D.M. Benoit, A-M. Seymour, C. Cawthorne, L.J. Higham, S.J. Archibald, Chem. Commun., 2016, 52, 7114

xiii O. Halter, R. Vasiuta, I. Fernandez, H. Plenio, Chem. Eur. J., 2016, 22, 18066.

xiv A.M. Christianson, F.P. Gabbai, Inorg. Chem., 2016, 55, 5828.

${ }^{x v}$ For example: S. Yamaguchi, S. Akiyama, K. Tamao, J. Organomet. Chem., 2002, 652, 3;

S. Yamaguchi, S. Akiyama, K. Tamao, J. Organomet. Chem., 2002, 646, 277; T. Hatakeyama, S. Hashimoto, M. Nakamura, Org. Lett., 2011, 13, 2130; J. Wang, Q. Zhao, C.M. Lawson, G.M. Gray, Opt. Commun., 2011, 284, 3090; K. Akasaka, T. Suzuki, H. Ohrui, H. Meguro, Anal. Lett., 1987, 20, 731; M. Onoda, S. Uchiyama, A. Endo, H. Tokuyama, T. Santa, K. Imai, Org. Lett., 2003, 5, 1459; N. Soh, O. Sakawaki, K. Makihara, Y. Odo, T. Fukaminato, T. Kawai, M. Irie, T. Imato, Bioorg. Med. Chem., 2005, 13, 1131; G.A. Lemieux, C.L. de Graffenried, C.R. Bertozzi, J. Am. Chem. Soc., 2003, 125, 4708.

xvi L. Ortego, J. Gonzalo-Asensio, A. Laguna, M.D. Villacampa, M.C. Gimeno, J. Inorg. Biochem., 2015, 146, 19; M.F. Fillat, M.C. Gimeno, A. Laguna, E. Latorre, L. Ortego, M.D. Villacampa, Eur. J. Inorg. Chem., 2011, 1487.

xvii Q. Zhang, G. Hua, P. Bhattacharyya, A.M.Z. Slawin. J.D. Woolins, Dalton Trans., 2003, 3250.

xviii J.E. Jones, B.M. Kariuki, B.D. Ward, S.J.A. Pope, Dalton. Trans., 2011, 40, 3498. 
${ }^{x i x}$ M.R.I. Zubiri, H.L. Milton, D.J. Cole-Hamilton, A.M.Z. Slawin, J.D. Woollins, Polyhedron, 2004, 23, 693.

${ }^{x x}$ L. Falivene, R. Credendino, A. Poater, A. Petta, L. Serra, R. Oliva, V. Scarano, L. Cavallo, Organometallics, 2016, 35, 2286

xxi T.E. Müller, M.P. Mingos, Transiton Met. Chem., 1995, 20, 533

xxii Z. Yoshida, F. Takabayashi, Tetrahedron, 1968, 24, 913.

xxiii E.E. Langdon-Jones, S.J.A. Pope, Coord. Chem. Rev., 2014, 269, 32.

${ }^{x x i v}$ T. Yanai, D.P. Tew, N.C. Handy, Chem. Phys. Lett., 2004, 393, 51.

${ }^{x x v}$ A. Vlček, S. Záliš, Coord. Chem. Rev., 2007, 251, 258.

xxvi Y. Zhao, D.G. Truhlar, Theor. Chem. Acc., 2008, 120, 215.

xxvii D. Andrae, U. Häußermann, M. Dolg, H. Stoll, H. Preuß, Theor. Chim. Acta, 1990, 77, 123.

xxviii T.H. Dunning, J. Chem. Phys., 1989, 90, 1007.

${ }^{x x i x}$ T.H. Dunning, K.A. Peterson, A.K. Wilson, J. Chem. Phys., 2001, 114, 9244.

${ }^{x x x}$ A.M. Sarotti, S.C. Pellegrinet, J. Org. Chem., 2009, 74, 7254.

${ }^{x x x i}$ A.M. Sarotti, S.C. Pellegrinet, J. Org. Chem., 2012, 77, 6059.

${ }^{x x x i i}$ B. Bodenant, F. Fages, M.-H. Delville, J. Am. Chem. Soc., 1998, 120, 7511; S.J.A. Pope, Polyhedron, 2007, 26, 4818.

xxxiii L.A. Mullice, F.L. Thorp-Greenwood, R.H. Laye, M.P. Coogan, B.M. Kariuki, S.J.A. Pope, Dalton Trans., 2009, 6836

${ }^{\text {xxxiv }}$ For example: S. Marpu, Z. Hu, M. A. Omary, Langmuir, 2010, 26, 15523

${ }^{x x x v}$ M. Frank, M. Nieger, F. Vogtle, P. Belser, A. von Zelewsky, L. De Cola, V. Balzani, F. Barrigelletti, L. Flamigni, Inorg. Chim. Acta, 1996, 242, 281.

${ }^{x x x v i}$ S.J. Coles, P.A. Gale, Chem. Sci., 2012, 3, 683

xxxvii CrysAlisPro Software System, Rigaku Oxford Diffraction, Yarnton, Oxford, UK (2015). xxxviii O.V. Dolomanov, L.J. Bourhis, R.J. Gildea, J.A.K. Howard, H. Puschmann, J. Appl. Cryst., 2009, 42, 339.

${ }^{\text {xxxix }}$ L. Palatinus, G. Chapuis, J. Appl. Cryst., 2007, 40, 786.

${ }^{\mathrm{xl}}$ G.M. Sheldrick, Acta Cryst., 2015, C27, 3.

xli M.J. Frisch, G.W. Trucks, H.B. Schlegel, G.E. Scuseria, M.A. Robb, J.R. Cheeseman, G. Scalmani, V. Barone, B. Mennucci, G.A. Petersson, H. Nakatsuji, M. Caricato, X. Li, H.P. Hratchian, A.F. Izmaylov, J. Bloino, G. Zheng, J.L. Sonnenberg, M. Hada, M. Ehara, K. 
Toyota, R. Fukuda, J. Hasegawa, M. Ishida, T. Nakajima, Y. Honda, O. Kitao, H. Nakai, T. Vreven, J.A. Montgomery Jr, J.E. Peralta, F. Ogliaro, M. Bearpark, J.J. Heyd, E. Brothers, K.N. Kudin, V.N. Staroverov, T. Keith, R. Kobayashi, J. Normand, K. Raghavachari, A. Rendell, J.C. Burant, S.S. Iyengar, J. Tomasi, M. Cossi, N. Rega, J.M. Millam, M. Klene, J.E. Knox, J.B. Cross, V. Bakken, C. Adamo, J. Jaramillo, R. Gomperts, R.E. Stratmann, O. Yazyev, A.J. Austin, R. Cammi, C. Pomelli, J.W. Ochterski, R.L. Martin, K. Morokuma, V.G. Zakrzewski, G.A. Voth, P. Salvador, J.J. Dannenberg, S. Dapprich, A.D. Daniels, O. Farkas, J.B. Foresman, J.V. Ortiz, J. Cioslowski, D.J. Fox, Gaussian 09, Revision C.01; Gaussian 09, Revision C.01; Gaussian Inc.: Wallingford CT, 2010.

xlii R. Ditchfield, J. Chem. Phys., 1972, 56, 5688.

xliii A.M. Lee, N.C. Handy, S.M. Colwell, J. Chem. Phys., 1995, 103, 10095.

xliv J. Tomasi, B. Mennucci, R. Cammi, Chem. Rev., 2005, 105, 2999. 